DOI:10.24193/tras.56E.2

Published First Online: 02/28/2019

\section{THE GEOGRAPHY OF TERRITORIAL \\ CAPITAL IN THE EUROPEAN UNION: \\ A MAP AND SEVERAL POLICY ISSUES}

\section{Valentin COJANU \\ Raluca ROBU}

\author{
Valentin COJANU \\ Professor, PhD, Department of International Business and \\ Economics, School of International Business and Economics, \\ Bucharest University of Economic Studies, \\ Bucharest, Romania \\ Tel.: 0040-729-919.980 \\ E-mail: valentin.cojanu@rei.ase.ro
}

\section{Raluca ROBU}

Assistant professor, PhD, Department of International Business and Economics, School of International Business and Economics, Bucharest University of Economic Studies,

Bucharest, Romania

Tel.: 0040-770-278.768

E-mail: raluca.robu@rei.ase.ro

\section{Abstract}

This paper investigates the territorial capital endowments across European regions. Data are collected at NUTS 2 level for all European regions, for the most recent year available, for several indicators that measure different components of territorial capital. Our evidence reveals several patterns of regional economic development, with specific configurations of the territorial assets, which further shed light on the connection between location, competitiveness and development.

Keywords: economic space, regional policy, development, location. 


\section{Introduction}

A competitive position can originate in multiple sources - managerial prowess, market structure, governmental intervention, or technological breakthrough, but one general term suffices to encapsulate them all: a favorable environment, internal and external to the company. This insight had been for long a staple of competitive analysis when Michael Porter (1990) turned it from a niche study of business strategists into a dominant topic of policy-making. As Porter concluded, policy effectiveness in terms of raising a country's living standards requires measures to unbind the competitive potential of domestic businesses. Vital to this process is the impact of location factors.

Porter's results resuscitated the tradition of 'spatially oriented economic studies' (Huggins and Izushi, 2015) and have since changed the way we relate competitiveness to development and to location. The conceptual trio has been an answer to account for the substantial transformations as to the organization of economic activities during the last decades. Commenting on the geographical scope of competitive advantage, Enright (1993) set the investigative questions in 'a model of the features that give one location an advantage over other locations for a given industry or set of industries'. It is a model which is framed at the junction between fragmentation and globalization of the economic space and implies, in a brief description, that competition across territories is gradually replacing competition between countries in the role of allocating resources and creating market value.

In this paper, we contemplate the model of locational features through the lens of the geography of territorial capital in the European Union (EU). As we will explain in the next section, the dedicated literature sets forth one unambiguous conclusion - territorial capital represents a key asset to gain competitive advantage - as well as many research hypotheses that still await substantiation about how to provide a coherent policy template with a territorial approach to underpinning competitiveness. Assuming we have become more knowledgeable about the causal nexus from location to competitive advantage to development, how are we supposed to turn this insight into effective policy-making?

Policy tasks for regional economies, especially for those cutting across national boundaries, do not yet converge towards an encompassing blueprint. To be sure, reviews inform regularly on the progress that has been made in regional policy development for domains such as environment, culture, innovation, energy or transportation; on its part, empirical evidence has been accumulating to defend the hypothesis regarding the positive role of territorial factors in supporting growth and competitive performance. Relevant though they may be, were we to join all pieces together in an articulated mechanism, we would soon have to confront two impenetrable issues: benefits for whom and within what territorial confines?

From this perspective, this study contributes with evidence regarding the endowment with territorial capital at EU regional level and the lessons we can draw to set a policy agenda for development and competitiveness. We define territorial capital 
along five components and nine indicators, and collect data for the EU NUTS 2 regions - national administrative units having a population between 800,000 and 3 million people. Data are processed through a statistical cluster analysis to show how regions group themselves together based on similar territorial endowments.

All this evidence reveals several patterns of regional economic development, with specific configurations of territorial assets, which further shed light on the connection between location and competitiveness and development. For at least two reasons absence of data for the entire sample and narrow scope of investigation - we have not been in the position to reach specific conclusions in respect to the impact of territorial assets on competitiveness and location. Instead, we describe a panoramic view of the conditions of geographic distribution of territorial capital in the EU that sheds light on the premises underlying the application of the conceptual trio in policy-making.

\section{Distribution of territorial capital in the EU: background and methodology}

Marketing has been the most important conduit for assimilating territory with a competitive asset. Companies have made known for long the origin of their goods or services with distinctive marks of location, such as 'Made in...' or 'Appellation d'origine protégée'. Economists, however, have been slow at integrating it into a conceptual framework, 'mostly taking it for granted' (Atzili and Kadercan, 2017) besides factoring distance in only for cost calculations. This is probably why, on their part, policy makers were not successful in transferring the business insight in relation to location into sensible public initiatives. The EU administration, for example, laid out a blueprint for a more competitive economy in two documents, the Lisbon (on growth) and Göteborg strategies (on sustainability), although 'in neither case were the spatial impacts explicitly considered' (Servillo, Atkinson and Russo, 2011). Similarly, the US Department of Commerce has been questioned about its capacity to support businesses in international competition on the argument that there are '379 separate economic development districts, many of which are too small to function as globally competitive entities' (Council on Competitiveness, 2010).

The recent period has shown, however, an increasing interest in documenting the role of territory as a competitive (and economic) asset. We attempt to highlight these contributions in the remaining of this section.

\subsection{Background}

In a celebrated passage of his Principles, Marshall yielded to a poetic exposition of the economic impact of location:

'When an industry has thus chosen a locality for itself, it is likely to stay there long: so great are the advantages which people following the same skilled trade get from near neighbourhood to one another. The mysteries of the trade become no mysteries; but are as it were in the air, and children learn many of them unconsciously.' (Marshall, 1920, p. 271) (our italics) 
In further paragraphs, Marshall pinned down those mysteries to a set of three key factors - 'the use of highly specialized machinery', 'a local market for special skill', and 'the growth of subsidiary trades' - that account for the benefits of location, an observation which continues to stand verbatim for a textbook lesson even these days (Krugman, Obstfeld and Melitz, 2012, p. 170). It is however his other locution - as it were in the air - which puzzled the economists trained in formal tradition. Even for the first geographical economists it was hard to overlook there is more than to reduce this apparently cloudy representation of proximity to no more than a physical concept. For example, Lösch noted: 'Countries and economic regions do not necessarily coincide. But political boundaries could cut through regular market networks, which results in economic losses' (Lösch, 1940, p. 197).

This insight led to an intense scrutiny of the concept of proximity that eventuated into varieties of proximities of ever more social and economic significance: relational, technological, cultural or institutional proximity (Ghemawat, 2001; Tremblay, Chevrier and Rousseau, 2004). With the resurgence of the literature emphasizing the economic impact of location (Perroux, 1954; Porter, 1998; Porter, 2000; OECD, 2001; Camagni and Capello, 2009; World Bank, 2009; Park, Nayyar and Low, 2013) in its various configurations - clusters, growth poles, learning regions, innovative milieu, territory as factor of production or territorial capital - has gradually become an indispensable part of an economist's toolkit to diagnose the competitive potential for a regional economy.

The OECD definition of territorial capital elaborates on Marshall's insight to a level of detail that gives credit to a remarkably large number of theoretical contributions. An area's endowment with territorial capital is determined by factors, tangible and intangible, such as: '(1) the area's geographical location, size, factor of production endowment, climate, traditions, natural resources, quality of life; (2) the agglomeration economies provided by its cities, but may also include its business incubators and industrial districts or other business networks that reduce transaction costs; (3) 'untraded interdependencies' such as understandings, customs and informal rules; and (4) 'the solidarity, mutual assistance and co-opting of ideas that often develop in clusters of small and medium-sized enterprises working in the same sector (social capital)' (OECD, 2001, p. 15).

Within this conception, each region has a different potential to nurture economic initiatives whose success depends on the existence of certain territorial assets in a certain combination and the local institutional capacity to capitalize on these assets. The hypothesis has been tested for the impact of the endowment with territorial assets on regional economic development, in most cases with conclusive results (Affuso and Camagni, 2010; Brasili, 2011; Brasili et al., 2012; Veneri, 2011). One caveat is however due in interpreting them. Difficulty in collecting statistical data, on the one hand, and multitude and subtlety of forms that territorial capital can take, on the other hand, have led researchers to focus on a narrow set of variables and, at times, on narrow conceptual interpretations. This is how emphasis varied between selected components of 'hard and soft territorial capital' over large geographical areas (Casi and Re- 
smini, 2012) and large sets of variables available for particular regions (Pompili and Martinoia, 2011; Veneri, 2011) or cities (Rota, 2010).

The upshot of these investigations consists irrevocably in arguments underscoring the potential of firms and entrepreneurs to achieve economic performance in local environments where they share the same representations, rules of action, and values. Territorial embedment, mostly represented by the connections created among local actors and between them and local immaterial influences, determines, to an important extent, the long-lasting prosperity of the local economies. Far for suggesting a recipe of taking advantage of territorial assets, these studies (see Affuso and Camagni, 2010) show only that competitive positions (or any other measure of economic success) can be achieved in different geographical spaces only by correlating decisions to the unique territorial capital of local economies.

Despite the relative success of the empirical work, authors like Sarmiento-Mirwaldt (2015) point nevertheless to 'a proverbial 'solution chasing a problem' approach to territorial development' meaning that competing definitions of what territorial capital would mean in practice makes it difficult to assess the political feasibility of a policy proposal. It is about who are supposed to benefit, the local social and economic subjects - easy to spot in industrial districts or administrative units, but difficult in regions of variable geometry; who is supposed to assume policy-making, the local institutions - Ackrill and Kay (2011, p. 75) define the term 'institutional ambiguity' referring to a policy-making environment of overlapping institutions lacking a clear hierarchy; over which territorial confines, the economic boundaries - the regional area for the best conditions of competitive development on a regional basis, that is, an area sufficiently large to allow for efficient levels of production, but fittingly small to capitalize on its specific territorial assets.

These theoretical queries are not abstractions, but a theme resounding from the real economy. The broadness of the concept of territorial capital has permitted ramifications in many directions of research, while at the same time it apparently has made its practical implications more impenetrable. For example, creativity, a hype currently adopted by many empirical studies, is apparently a component hard to integrate. Servillo, Atkinson and Russo (2011) remark that 'the process by which pools of creative talent lead place economies to be competitive remains a 'black box". At a more general level on the policy side, there is a widespread concern about the inability of locations of 'deep-seated poverty' to absorb and learn from the proximity to growth centers. The cause lies unambiguously with 'the limit of these theoretical constructs to guide policy' (OECD, 2001, p. 180), as does for the long-term evolution of polarized inter-regional growth (OECD, 2016, p. 26).

The 2008 global crisis marked a point of critical assessment of economic theories in general, including the relatively recent researches on territorial capital. Delgado, Porter and Stern's (2015) study on region-industries in the United States from 2003 until 2011 shows that strong clusters improve not only the regional employment growth, but also the resilience of regional economies to downturns. Evidence from France 
(Martin, Mayer and Mayneris, 2013) comes with a contrary result: it shows that during the recession period of 2008-2009, dependence on intra-firm linkages made firms in clusters that have benefited from targeted industrial policy implemented in 2005 to register lower resilience scores ${ }^{1}$. The range of practical issues points to the task of a renewed focus on the conceptual framework as illustrated in the queries we have suggested above. From that set, this paper chooses to narrow the investigation on the geographical aspect.

\subsection{Methodology and data collection}

The objective is to visualize endowments with territorial capital in the EU at regional level and reveal the patterns that emerge from this geographical distribution. We define territorial capital with the help of five components or assets (see Table 1), which are commonly acknowledged for their contribution towards creating a competitive environment and ultimately prosperity for a regional economy. To keep as large a geographical coverage as possible given the available statistics, we approximate the 'regional economy' to the administrative units NUTS 2 for each EU member country, which Eurostat, the EU's statistical office, defines as 'basic regions for the application of regional policies' in the EU (Eurostat, 2017).

The geographical scope of our analysis thus consisted of all 276 NUTS 2 regions of the EU28. Due to incomplete data availability, we were finally able to count only 138 of them. We input the values of the nine indicators for the 138 regions into a statistical cluster analysis using the Ward method which permits to form clusters of regions based on observations that have the smallest variance without prior knowledge about the number of resulting groupings. The results are coloured distinctly for each cluster and drawn on a map indicating the distribution of territorial capital across European regions.

The choice for the components of territorial capital results directly from the theoretical framework integrating location into development and competitive analyses. We call these components assets due to their role in translating a given endowment into a marketable resource (capital) in the marketplace.

The relational asset of territorial capital is perhaps the most distinctive. It has a double nature, social and economic, reflecting the twin determinants of interconnectedness - inter-personal relations and the material setting making them possible. Creativity makes impact through locally inherited pools of skills and talent, as well as the ordinary industry of producing cognitive capital in educational and research structures. Natural capital is the essential geographical feature of location, whereby the production processes assimilate its landscape and environment. Finally, we have selected development to consider the characteristics of the existing development stage as a territorial asset, which influences local economies in a circular cumulative

1 Measured in higher survival probability of firms on export markets and higher growth rate of their exports. 
Table 1: The components of territorial capital and selected indicators

\begin{tabular}{|c|c|c|c|}
\hline $\begin{array}{l}\text { Components } \\
\text { (assets) }\end{array}$ & Description & Indicators & $\begin{array}{l}\text { Measurement unit } \\
\text { (data availability) }\end{array}$ \\
\hline $\begin{array}{l}\text { (Relational) } \\
\text { Social }\end{array}$ & Cohesion & $\begin{array}{l}\text { Long term unemployment ( } 12 \text { months and } \\
\text { more) by NUTS } 2 \text { regions (unemployment) }\end{array}$ & $\begin{array}{l}\text { Percentage of active population } \\
\text { (2014) }\end{array}$ \\
\hline $\begin{array}{l}\text { (Relational) } \\
\text { Economic }\end{array}$ & $\begin{array}{c}\text { Built capital } \\
\text { (stock of capital) }\end{array}$ & $\begin{array}{l}\text { Road, rail and navigable inland waterways } \\
\text { networks by NUTS } 2 \text { regions (Motorways + } \\
\text { Total railway lines) (transport) }\end{array}$ & $\begin{array}{l}\text { Kilometers per thousand square } \\
\text { kilometers (2013) }\end{array}$ \\
\hline \multirow[t]{3}{*}{ Creativity } & $\begin{array}{l}\text { Creative } \\
\text { employment }\end{array}$ & Share of creative workforce & $\begin{array}{l}\text { Number of jobs in the creative } \\
\text { workforce per active population } \\
\text { (Change in the share of creative } \\
\text { workforce population between } \\
2001 \text { and 2008) }\end{array}$ \\
\hline & Tacit knowledge & $\begin{array}{l}\text { Total intramural R\&D expenditure (GERD) by } \\
\text { sectors of performance and NUTS } 2 \text { regions } \\
\text { (all sectors) (research) }\end{array}$ & Euro per inhabitant (2013) \\
\hline & Innovation & $\begin{array}{l}\text { Patent applications to the European Patent } \\
\text { Office by priority year by NUTS } 3 \text { regions } \\
\text { (patents) }\end{array}$ & $\begin{array}{l}\text { Patent applications per million } \\
\text { of active population (2010) }\end{array}$ \\
\hline \multirow[t]{2}{*}{ Natural } & Landscape & $\begin{array}{l}\text { Number of establishments, bedrooms and } \\
\text { bed-places by NUTS } 2 \text { regions (tourism) }\end{array}$ & Number of bed-places (2014) \\
\hline & Environment & $\begin{array}{l}\text { Tillage methods: number of farms and areas } \\
\text { by economic size of farm (SO in euros) and } \\
\text { NUTS } 2 \text { regions (agriculture) }\end{array}$ & $\begin{array}{l}\text { Utilized agricultural area (ha) } \\
\qquad(2010)\end{array}$ \\
\hline \multirow[t]{2}{*}{$\begin{array}{c}\text { Level of } \\
\text { development }\end{array}$} & $\begin{array}{l}\text { Institutional } \\
\text { capacity }\end{array}$ & $\begin{array}{l}\text { Gross domestic product (GDP) at current } \\
\text { market prices by NUTS } 2 \text { regions }\end{array}$ & Euro per inhabitant (2013) \\
\hline & & $\begin{array}{l}\text { Income of households by NUTS } 2 \text { regions } \\
\text { (disposable income, net) }\end{array}$ & Euro per inhabitant (2012) \\
\hline
\end{tabular}

Source: In selecting the components and indicators, we have drawn on the following sources: Affuso and Camagni (2010), Brasili (2011), Brasili et al. (2012), Camagni, Caragliu and Perucca (2011), Casi and Resmini (2012), Pompili and Martinoia (2011), Rota (2010), Veneri (2011). The data source was Eurostat from the European Commission (2016b), with one exception, for creative workforce, when we used the Espon Database Portal (2011).

* We considered the latest year for which data are available for all or most of EU's regions

fashion as the created value is introduced back into the economy through expenditures, investments, and accumulated experience.

Making the right choice as to the variables quantifying the endowments with territorial capital was inevitably dependent on the research constraints and thus ran into difficulties - of statistical and conceptual nature. On the statistical side, data could not be found for the whole range of our selected indicators for the regions of Croatia, France, Greece, Portugal, UK, and, in part, Germany. This absence of data reduced the number of observations from 276 to 138 . As a result, the map we present in the findings section contains notable empty spaces. Important though they are for a complete spatial representation, these missing spots bear however little analytical 
weight for at least two reasons. First, the sample is sufficiently large to fit adequately our methodological design. We have arrived at a set of clusters that, by number and composition, is illustrative for varying patterns of economic agglomerations. Second, the sample is sufficiently diverse in terms of spatial representation and regional characteristics. Consequently, the results should not be qualified in respect to how and by how much the conclusions could have changed had we counted on data for all EU NUTS 2 regions. On the conceptual side, the theory is by far richer in assumptions and hypotheses than one can adequately test empirically. What we have done was to select, given the statistical limitations, the variables that would resemble most faithfully each asset's theoretical significance.

The relational asset is equated with 'the concept of local milieu, meaning a set of proximity relations' (Camagni, 2007), which bring together and integrate social/ personal networks. Its core attribute is cohesion (Casi and Resmini, 2012) - the degree and quality of innumerable interdependencies taking form across a territory. Arguably, scholars have argued that trust is probably the most important component of social capital, although other variables may be added such as 'people at risk of poverty or social exclusion', 'personal networks', or 'values'.

Eurostat measures cohesion through long-term unemployment because 'longterm unemployment would contribute to sustainable growth and cohesion' (European Commission, 2016a). Long-term unemployment is a matter that erodes relational capital from a social perspective. From an economic perspective, the choice of variables is admittedly more generous. The stock of capital influencing cohesion may be found in business infrastructures such as global value chains or business networks, as well as transport and communication endowments. Physical connectivity between regions and economic agglomeration and, implicitly, people and economic agents, depend on the density of the available transport infrastructure. Basically, our choice for 'road, rail and navigable inland waterways networks' may serve well our purpose.

Creativity is similarly a broad concept integrating to some greater extent non-quantifiable descriptors like know-how, tacit knowledge, traditions etc. Under this rubric, we include three indicators: 'the share of creative workforce in the active population', 'research and development expenditure' and 'the number of patent applications'. These indicators cover all the aspects of the innovative potential: human potential to innovate, the support of cognitive knowledge, through expenditures in R\&D (research and development), and the results of creative activity (patents).

The natural capital is described through 'landscape', 'urbanization', and 'environment'. We use proxies that capture the efforts made by people to valorise certain natural resources, such as touristic and agricultural potential. The input from development consists generally of the quality of institutions - the capability of local government and business representatives to make most of the territorial endowments. Our indicators - 'Gross domestic product (GDP) per capita' and 'income of households' - represent a remote equivalent of the intended variable, but it is safe to assume that higher values are indicative of a superior institutional potential. 


\section{Distribution of territorial capital in the EU: findings}

The cluster analysis results in 14 clusters. Their spatial distribution and country composition are depicted in Figure 1, A and B, respectively. There are three patterns that emerge from our map.

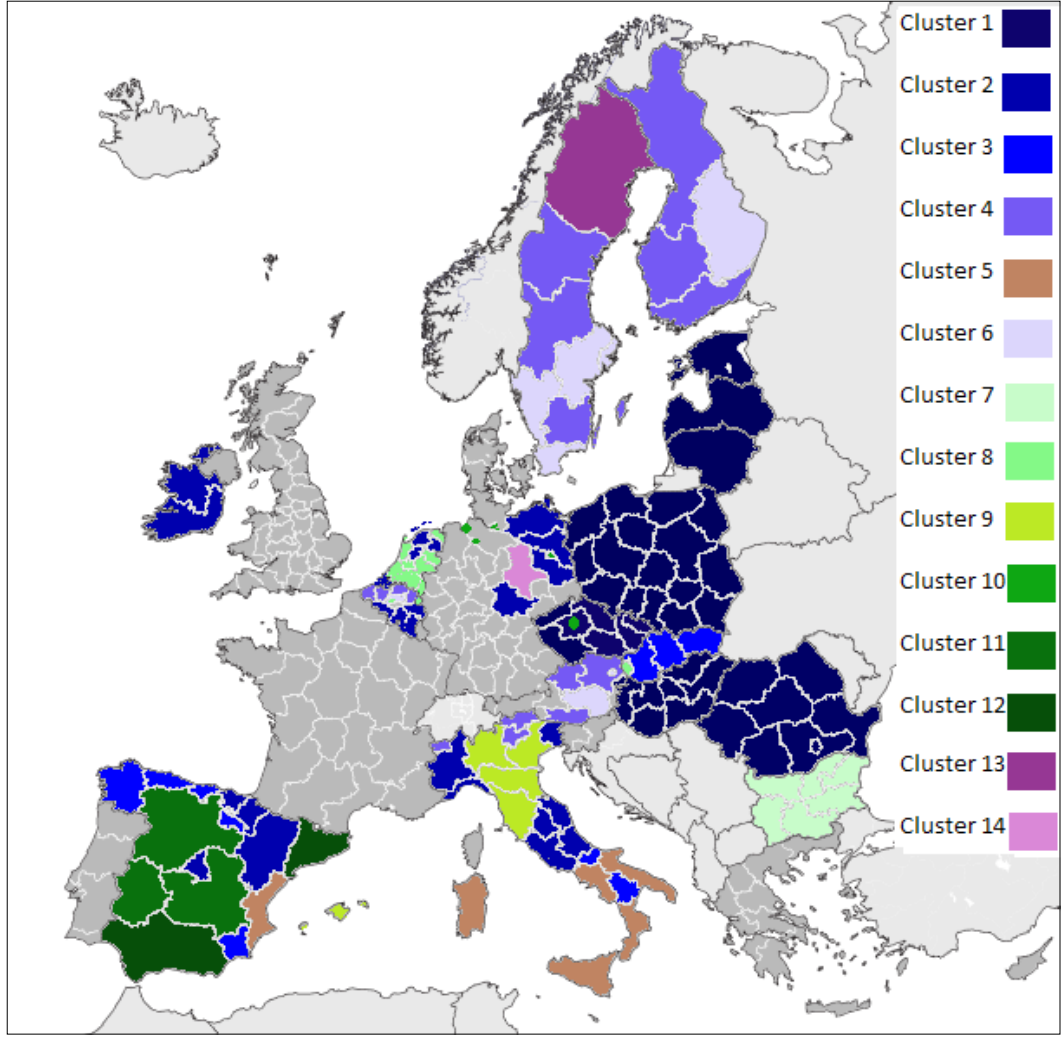

1A. Map of regional clusters

Source: Authors' work

1B. Cluster composition by country ${ }^{*}$

\begin{tabular}{cl}
\hline Cluster & \multicolumn{1}{c}{ Cluster countries } \\
\hline 1 & $\begin{array}{l}\text { Czech Republic, Estonia, Hungary, Latvia, Lithuania, } \\
\text { Poland, Romania }\end{array}$ \\
2 & Belgium, Germany, Spain, Ireland, Italy, Netherlands \\
3 & Spain, Italy, Slovakia \\
4 & Austria, Belgium, Finland, Italy, Sweden \\
5 & Spain, Italy \\
6 & Austria, Belgium, Finland, Sweden \\
7 & Bulgaria \\
\hline
\end{tabular}

\begin{tabular}{cl}
\hline Cluster & \multicolumn{1}{c}{ Cluster countries } \\
\hline 8 & Belgium, Netherlands, Slovakia \\
9 & Spain, Italy \\
10 & Czech Republic, Germany \\
11 & Spain \\
12 & Spain \\
13 & Sweden \\
14 & Germany \\
\hline
\end{tabular}

*Annex 1 illustrates the cluster composition by region.

Source: Authors' work

Figure 1: Distribution of regional territorial capital at EU regional level 
First, the map reveals one homogeneous grouping represented by almost the entire area of the Central and Eastern European countries (CEEC). The structural similarities inherited from the communist era still bind them together. The CEEC cluster (\#1) exhibits relatively small values for all indicators, the least ones for the level of development (GDP and income). It also contains the region with the lowest share of creative workforce - Sud Muntenia in Romania.

However, two cases deviate from the CEEC homogeneity, although they do but prove the general observation of a three-pronged pattern of distribution. First, Bulgarian regions find themselves in a cluster of their own (\#7) as their indicator values are even lower than those of their peers. Cluster \#1's average GDP/capita stands at $€ 9,700$ in comparison with $€ 5,000$ in cluster \#7. The number of patents per million of active people and R\&D expenditures are more than triple on average in cluster \#1 than those for Bulgarian regions.

Second, the regions of the Czech Republic and Slovakia - known as one single country, Czechoslovakia, before its dissolution in 1993 - find their cluster place in a pattern resembling our three-pronged typology. The regions containing their capitals belong to clusters of high locational advantages - either forming a compact territory like the case of Prague adjoining Berlin, Bremen, and Hamburg in a region of the densest transport infrastructure, or appearing as a disjoint location like the presence of Bratislava in the same cluster with contiguous Dutch regions. Their other regions are found in cluster \#1 for Czech Republic, or in cluster \#3, for Slovakia. The latter grouping, which includes regions from Spain (in North-East) and Italy (two regions in Southern Italy, Mezzogiorno), exhibits in fact values similar to those of cluster \#1 for most indicators although at a sizeable higher level of development - the GDP and income levels are double than those of cluster \#1 and higher than the average for the 138 regions.

A second pattern of regional configuration consists in clusters where one region is the only member or joins other regions as a disjoint location. Two reasons could explain why this pattern is expected to be a pervasive rather than singular characteristic of the economic landscape. For one thing, geographical remoteness alone suffices to singularize regional economies - as in cluster \#13, whose only region, Övre Norrland in Northern Sweden, with a very high GDP/capita and good values for research and patents, is scarcely populated and hence poorly endowed with transport infrastructure. For another, some regions appear insulated amid larger territorial blocs either in clusters of their own, or in clusters of geographically remote regions. An example of the former case is Sachsen-Anhalt in the centre of Germany in cluster \#14, a region with the highest share of creative work-force, almost seven times bigger than the second most performing region, Stockholm. As for the latter case, geographically disjoined regions, one or two in most cases, get themselves clustered with compact territories thanks to close indicator values as we exemplify further.

Finally, a third pattern of clusters consists of a more varied territorial fragmentation that characterizes advanced economies or regions of relatively higher locational 
attractiveness. This variety, however, comes down to a limited number of cases as suggested by our evidence:

\section{Compact territories at country level}

The most visible examples are characteristic for countries of large territories like Italy, Spain, and Sweden, although smaller country sizes - e.g., the Netherlands, Belgium, Finland - may qualify too. Italy is divided in almost three parts: Northern Italy in cluster \#4, Southern Italy in cluster \#5, in addition to the two Southern regions in cluster \#3, as well as a large area highly specialized in tourism - Veneto, Toscana, Emilia-Romagna, and Lombardia in cluster \#9. The map in Belgium overlaps exactly the known division between the Flemish and Walloon regions: four regions in cluster \#4 neighbour the Netherlands, while three regions in cluster \#2 border France, Luxembourg, and Germany. Relatively large territories at sub-national level appear also in central Spain - three areas of three regions each: in central Spain, by far the most developed agricultural area in our sample, in a cluster (\#11) of their own, bordering France in cluster \#2 and the Atlantic shore in cluster \#3; in the Netherlands - in cluster $\# 8$, a large compact area of seven Dutch regions; in Sweden - in clusters \#4 and \#6, Finland or Ireland.

\section{Disjoint territories at country level or European level}

In most cases, i.e. clusters \#2, 3, 4, 5, 6 and 9, regions group together due to similar endowments, although their grouping bears no geographical interpretation. Possibly, this is the most expected result: on a large territory, especially of common political, economic, and social heritage, there is rare a case when the regional economies would come apart so indistinguishably.

In several cases, a country may exhibit one or two regional groupings in the same cluster, although not in geographical proximity. Spain provides again some examples: two Spanish regions, Cataluña and Andalucía, which are among the highest European touristic attractions, form a cluster (\#12) of their own or Comunidad de Madrid in cluster \#2 joins other Spanish yet not contiguous regions. Other examples: Austria - Wien and Steiermark alone in cluster \# 6, the Netherlands - Groningen in cluster \#8, etc.

\section{Compact territories at supra-national level}

On the assumption that territorial capital represents an essential component of an economic space, the findings point emphatically to the existence of regional economies at supra-national level. The relentless removal of cross-border barriers due to European integration or merely geographical proximity ushered in cross-border economic configurations. In our sample, deprived of a large set of data though it may be, most visible is the case of the neighbouring regions of Sweden and Finland in cluster \#4 and again in cluster \#6, but also the space configured by the Czech and German regions in cluster $\# 10$ or the proximity of Balearic Islands of Spain to the touristic Italian area in cluster $\# 9$ are equally worth remarking. 


\section{Concluding remarks on policy issues}

When a certain level of detail is imprinted on a map, which is then scaled at geographically relevant size, that map may inspire practical action. This has been at least the premise of this paper - to work with location-specific data to highlight policy issues regarding the spatial distribution of territorial assets. The new direction of competition is not irreversible though - every step toward severing links within the global economy would make us adjust the theoretical framework from the outset that is thinking primarily from a nation-state perspective. For now, however, the conditions of production and trade favour a hub-and-spoke landscape, within which the economic space becomes increasingly important in creating value across rather than within national borders.

Our findings suggest that fragmentation of the economic space - i.e., a compact territory of regions at either sub- or supra-national level with similar endowments - is almost inexistent in the territorial confines of former communist countries, but remarkably varied for advanced countries. We expect the regional configuration of the CEEC space to borrow in time features characteristic for the rest of European area because development is about to work gradually yet continuously on the quality and structure of territorial assets. As much as our map can reveal, what is to be expected from that transformation in terms of policy issues?

On the one hand, perhaps the most obvious conclusion is that mapping territorial capital at regional level resembles the familiar picture of relatively large yet spatially confined regions endowed with similar assets. The key difference with past analyses consists in the change of perspective: national borders may or not may appear as common demarcations of similar endowments with territorial capital. Except for the CEEC space, the rule is that national territories are rather fragmented spaces revealing common historical, cultural or socio-economic legacy of certain neighboring regions.

We described the main characteristics of each cluster showing the unique combination of territorial endowments in different proportions. It follows that the old debate about a country's 'balanced development' should be replaced by or at least complemented with a different theme, namely the institutional and business local capabilities of translating the assets in increased economic value; in other words, we should consider the relevant spatial unit of analysis in terms of similar local conditions for business development rather than common macroeconomic constraints.

Although the new focus might well co-exist with policy initiatives at national level, it would address regional problems more directly and in a more effective way. More directly, because one-size-fits-all prescriptions degrades considerably when the needs of agglomerations are questioned: the territorial capital comes in many varieties and is usually tacit and territorially specific. In a more effective way because a questionable economic practice - i.e., redistributive funding from rich to poor regions - should be scaled back to the point of being irrevocably eliminated. The transfer of 
resources between regions becomes visibly an economic non-sense when we view regional economies through the lens of low-high potential of territorial attractiveness: the regions are not necessarily poor or rich, nor are they aligned in terms of business needs and capabilities with other economies.

On the other hand, once we look beyond the national borders, we face equally a highly fragmented landscape, although this time we lack the conventional point of reference - a nation-state's frontier. And this finding raises at least two policy issues. First, we should acknowledge the reality of cross-border regions with identarian characteristics in stark contrast with their country of origin. For example, remember that Prague is, according to our analysis, part of a relatively advanced economy spreading well into German territory while the rest of its country's regions belong to the CEEC space.

In this regard at least, local initiatives have made for long headway especially under the guidance and with financial support of EU dedicated programs. It is in this context that specific territorial proposals have taken form from simple territorial arrangements to more complex ones. For example, Luxembourg proposed the creation of a cross-border polycentric region in the Grande Région that spans Luxembourg and parts of Belgium, France and Germany.

From a trans-national perspective, a second policy issue is related to the case of isolated or disjoint regions. To put it differently, we confront the situation when a region does not find its place - in terms of territorial endowments - within given borderlines (of a nation-state or neighbouring regions). The case of disjoint regions poses a different challenge. As a pattern of regional distribution of territorial capital, it is not an unusual finding insofar as similar endowments are expected to be revealed across large territories. One may find parallels among regional economies from different continents (see Dupeyron, 2008). However, as a policy issue, this case is more complex. When we illustrate the case of the two Spanish regions in cluster \#12, for example, we wonder how this analytical finding makes sense for policy-making. Two scenarios may be considered.

In one scenario, the existence of a regional economy as part of a national territory with different local assets as compared to the neighbouring regions would make no difference to the policy approach as practiced so far at national level. Perhaps, more sensible to the needs and potential of local economies, the policy-makers would try to introduce more place-based policies instead of macroeconomic planning. As for a second scenario, a location might have a too small geographical size to stand alone as a single regional economy. In fact, we have used a statistical definition for a regional economy, i.e. NUTS 2, which suggests it might exist in fact as a self-contained administrative unit. However, we have not checked specifically if and where this case arises in our sample. For isolated regions, this would be an analytical requirement before proceeding to sketch a new paragraph in a policy agenda. 


\section{References:}

1. Ackrill, R. and Kay, A., 'Multiple Streams in EU Policy-Making: The Case of the 2005 Sugar Reform', 2011, Journal of European Public Policy, vol. 18, no. 1, pp. 72-89.

2. Affuso, A. and Camagni, R., 'Territorial Capital and Province Performance in the Latin Arch: An Econometric Approach', 2010, [Online] available at http://www.gruppo servizioambiente.it/aisre/pendrive2010/pendrive/paper/affuso1.pdf, accessed on February 23, 2018.

3. Atzili, B. and Kadercan, B., 'Territorial Designs and International Politics: The Diverging Constitution of Space and Boundaries', 2017, Territory, Politics, Governance, vol. 5, no. 2, pp. 115-130.

4. Brasili, C., 'Local and Urban Development in the European Union. New Challenges for European Regions and Urban Areas in a Globalised World', the 51 ${ }^{\text {st }}$ Congress of the European Regional Science Association, Barcelona, Spain, 30 August - 3 September, 2011.

5. Brasili, C., Saguatti, A., Benni, F., Marchese, A. and Gandolfo, D., 'The Impacts of the Economic Crisis on the Territorial Capital of Italian Regions. Regions in Motion Breaking the Path', the $52^{\text {nd }}$ Congress of the European Regional Science Association, Bratislava, Slovakia, August, 2012.

6. Camagni R. and Capello R., 'Knowledge-Based Economy and Knowledge Creation: The Role of Space', in Fratesi U. and Senn L. (eds.), Growth and Competitiveness in Innovative Regions: Balancing Internal and External Connections, Berlin: Springer Verlag, 2009, pp. 145-166.

7. Camagni, R., 'Towards a Concept of Territorial Capital. Local Governance and Sustainable Development.', Joint Congress of the European Regional Science Association (47 ${ }^{\text {th }}$ ) and ASRDLF Association de Science Regionale de Langue Francais, Paris, France, 29 August - 2 September, 2007.

8. Camagni, R., Caragliu, A. and Perucca, G., 'Territorial Capital: Relational and Human Capital', Paper draft, 2011, [Online] available at http://www.inter-net.it/aisre/minisito/ CD2011/pendrive/Paper/Camagni_Caragliu_Perucca.pdf, accessed on January 21, 2018.

9. Casi, L. and Resmini, L., 'Foreign Direct Investment and Growth: The Role of Regional Territorial Capital', European Trade Study Group (ETSG), $14^{\text {th }}$ Annual Conference, Leuven, Belgium, September, 2012.

10. Council on Competitiveness, 'Collaborate. Leading Regional Innovation Clusters', June, 2010, Washington, [Online] available at http://www.compete.org/publications/ detail/1384/leading-regional-innovation-clusters/, accessed on January 23, 2018.

11. Delgado, M., Porter, M.E. and Stern, S., 'The Resilience of Clusters: Evidence from the Great Recession', Paper draft, 2015, [Online] available at https://www.industrystudies conference.org/conference/papers/download/23, accessed on March 3, 2018.

12. Dupeyron, B., 'Cascadia Revisited from European Case Studies: The Socio-Political Space of Crossborder Networks', 2008, Canadian Political Science Review, vol. 2, no. 2, pp. 84-103.

13. Enright, M.J., Regional Clusters and Economic Development: A Research Agenda, Harvard: Division of Research, Harvard Business School, 1993.

14. Espon Database Portal, 'Creative Workforce Data', 2011, [Online] available at http:// database.espon.eu/db2/resource?idCat=73, accessed on April 2, 2017. 
15. European Commission, 'Eurostat - Nomenclature of Territorial Units for Statistics - Overview', 2015, [Online] available at http://ec.europa.eu/eurostat/web/nuts/over view, accessed on April 5, 2018.

16. European Commission, 'Long-term Unemployment: Council Recommendation - Frequently Asked Questions', February, Brussels, 2016a.

17. European Commission, 'Eurostat Database', 2016b, [Online] available at http://ec.eu ropa.eu/eurostat/web/regions/data/database, accessed on April 3, 2017.

18. Eurostat, 'NUTS - Nomenclature of Territorial Units for Statistics - Overview', [Online] available at http://ec.europa.eu/eurostat/web/nuts, accessed on September 27, 2017.

19. Ghemawat, P., 'Distance Still Matters: The Hard Reality of Global Expansion', 2001, Harvard Business Review, September issue, [Online] available at https://hbr.org/2001/09/ distance-still-matters-the-hard-reality-of-global-expansion, accessed on January 23, 2018.

20. Huggins, R. and Izushi, H., 'The Competitive Advantage of Nations: Origins and Journey', 2015, Competitiveness Review, vol. 25, no. 5, pp. 458-470.

21. Krugman, P., Obstfeld, M. and Melitz, M.J., 'International Economics. Theory and Policy', London: Pearson, 2012.

22. Lösch, A., The Economics of Location, New Haven: Yale University Press, 1954 (1940).

23. Marshall, A., Principles of Economics, $8^{\text {th }}$ edition, London: Macmillan, 1920 (1890).

24. Martin, P.T., Mayer, T. and Mayneris, F., 'Are Clusters More Resilient in Crises? Evidence from French Exporters in 2008-2009', The Factory Free Economy: What Next for the $21^{\text {st }}$ Century Conference, Paris, France, 2013.

25. OECD, 'OECD Regional Outlook 2016. Productive Regions for Inclusive Societies', Paris: OECD Publishing, 2016.

26. OECD, 'Territorial Outlook', Paris: OECD Publishing, 2001.

27. Park, A., Nayyar, G. and Low, P., Supply Chains Perspectives and Issues. A Literature Review, Geneva: World Trade Organization, 2013.

28. Perroux, F., L'Europe sans ravage, Paris: Presses Universitaires de France, 1954.

29. Pompili, T. and Martinoia, M., 'Building Synthetic Indicators for Aspects of Territorial Capital towards Their Impact on Regional Performance', the $51^{\text {st }}$ Congress of the European Regional Science Association, Barcelona, Spain, August 30 -September 3, 2011.

30. Porter, M.E., 'Location, Competition, and Economic Development: Local Clusters in a Global Economy', 2000, Economic Development Quarterly, vol. 14, no. 1, pp. 15-34.

31. Porter, M.J., 'Clusters and the New Economics of Competition', 1998, Harvard Business Review, November-December issue, [Online] available at https://hbr.org/1998/11/clus ters-and-the-new-economics-of-competition, accessed on March 23, 2018.

32. Rota, F.S., 'The Territorial Embedment of Global Industrial Networks. Theoretical Insights and Evidences from Foreign MNCs' Affiliates in Turin (Italy)', 2010, Paper draft, [Online] available at https://www.researchgate.net/profile/Francesca_Rota/publica tion, accessed on January 19, 2018.

33. Sarmiento-Mirwaldt, K., 'Can Multiple Streams Predict the Territorial Cohesion Debate in the EU?', 2015, European Urban and Regional Studies, vol. 22, no. 4, pp. 431-445.

34. Servillo, L., Atkinson, R. and Russo, A.P., 'Territorial Attractiveness in EU Urban and Spatial Policy: A Critical Review and Future Research Agenda', 2011, European Urban and Regional Studies, vol. 19, no. 4, pp. 349-365. 
35. Tremblay, D.G., Chevrier, C. and Rousseau, S., 'The Montreal Multimedia Sector: District, Cluster or Localized System of Production?', in Wolfe, D. and Lucas, M. (eds.), Clusters in A Cold Climate: Innovation Dynamics in a Diverse Economy, Montreal and Kingston: McGill-Queen's University Press, 2004, pp. 165-194.

36. Veneri, P., 'Territorial Identity in Italian NUTS-3 Regions', 2011, Paper draft, [Online] available at $\mathrm{http} / / / \mathrm{www}$.grupposervizioambiente.it/aisre/pendrive2011/pendrive/Pa per/paper_vert_AN_june_2011.pdf, accessed on January 23, 2018.

37. World Bank, 'World Development Report 2009: Reshaping Economic Geography', Washington: World Bank Group, 2009, [Online] available at http://documen ts.worldbank.org/curated/en/730971468139804495/pdf/437380REVISED01BLIC109 7808213760720.pdf, accessed on February 23, 2018. 
Annex 1: Clusters' components at EU NUTS 2 level

\begin{tabular}{|c|c|c|c|c|c|}
\hline EU region & Region & $\begin{array}{l}\text { Cluster } \\
\text { number }\end{array}$ & EU region & Region & $\begin{array}{l}\text { Cluster } \\
\text { number }\end{array}$ \\
\hline Strední Cechy & CZO2 & 1 & Niederösterreich & AT12 & 4 \\
\hline Jihozápad & CZO3 & 1 & Kärnten & AT21 & 4 \\
\hline Severozápad & CZO4 & 1 & Oberösterreich & AT31 & 4 \\
\hline Severovýchod & CZ05 & 1 & Prov. Antwerpen & BE21 & 4 \\
\hline Jihovýchod & CZO6 & 1 & Prov. Limburg (BE) & BE22 & 4 \\
\hline Strední Morava & CZ07 & 1 & Prov. Oost-Vlaanderen & BE23 & 4 \\
\hline Moravskoslezsko & CZ08 & 1 & Prov. West-Vlaanderen & BE25 & 4 \\
\hline Eesti & EE00 & 1 & Etelä-Suomi & Fl18 & 4 \\
\hline Közép-Magyarország & HU10 & 1 & Länsi-Suomi & Fl19 & 4 \\
\hline Közép-Dunántúl & HU21 & 1 & Pohjois- ja Itä-Suomi & Fl1A & 4 \\
\hline Nyugat-Dunántúl & HU22 & 1 & Valle d'Aosta/Vallée d'Aoste & ITC2 & 4 \\
\hline Dél-Dunántúl & HU23 & 1 & $\begin{array}{l}\text { Provincia Autonoma di } \\
\text { Bolzano/Bozen }\end{array}$ & ITD1 & 4 \\
\hline Észak-Magyarország & HU31 & 1 & Provincia Autonoma di Trento & ITD2 & 4 \\
\hline Észak-Alföld & HU32 & 1 & Småland med öarna & SE21 & 4 \\
\hline Dél-Alföld & HU33 & 1 & Norra Mellansverige & SE31 & 4 \\
\hline Lietuva & LT00 & 1 & Mellersta Norrland & SE32 & 4 \\
\hline Latvija & LV00 & 1 & Comunidad Valenciana & ES52 & 5 \\
\hline Lódzkie & PL11 & 1 & Canarias (ES) & ES70 & 5 \\
\hline Mazowieckie & PL12 & 1 & Campania & ITF3 & 5 \\
\hline Malopolskie & PL21 & 1 & Puglia & ITF4 & 5 \\
\hline Slaskie & PL22 & 1 & Calabria & ITF6 & 5 \\
\hline Lubelskie & PL31 & 1 & Sicilia & ITG1 & 5 \\
\hline Podkarpackie & PL32 & 1 & Sardegna & ITG2 & 5 \\
\hline Swietokrzyskie & PL33 & 1 & Wien & AT13 & 6 \\
\hline Podlaskie & PL34 & 1 & Steiermark & AT22 & 6 \\
\hline Wielkopolskie & PL41 & 1 & Prov. Vlaams-Brabant & BE24 & 6 \\
\hline Zachodniopomorskie & PL42 & 1 & Helsinki-Uusimaa & $\mathrm{Fl} 13$ & 6 \\
\hline Lubuskie & PL43 & 1 & Stockholm & SE11 & 6 \\
\hline Dolnoslaskie & PL51 & 1 & Östra Mellansverige & SE12 & 6 \\
\hline Opolskie & PL52 & 1 & Sydsverige & SE22 & 6 \\
\hline Kujawsko-Pomorskie & PL61 & 1 & Västsverige & SE23 & 6 \\
\hline Warminsko-Mazurskie & PL62 & 1 & Severozapaden & BG31 & 7 \\
\hline Pomorskie & PL63 & 1 & Severen tsentralen & BG32 & 7 \\
\hline Nord-Vest & R011 & 1 & Severoiztochen & BG33 & 7 \\
\hline Centru & R012 & 1 & Yugoiztochen & BG34 & 7 \\
\hline Nord-Est & $\mathrm{RO} 21$ & 1 & Yugozapaden & BG41 & 7 \\
\hline Sud-Est & $\mathrm{RO} 22$ & 1 & Yuzhen tsentralen & BG42 & 7 \\
\hline Sud - Muntenia & RO31 & 1 & Région de Bruxelles-Capitale & BE10 & 8 \\
\hline
\end{tabular}




\begin{tabular}{|c|c|c|c|c|c|}
\hline EU region & Region & $\begin{array}{l}\text { Cluster } \\
\text { number }\end{array}$ & EU region & Region & $\begin{array}{l}\text { Cluster } \\
\text { number }\end{array}$ \\
\hline Bucuresti - Ilfov & $\mathrm{RO} 32$ & 1 & Groningen & NL11 & 8 \\
\hline Sud-Vest Oltenia & RO41 & 1 & Overijssel & NL21 & 8 \\
\hline Vest & RO42 & 1 & Gelderland & NL22 & 8 \\
\hline Prov. Hainaut & BE32 & 2 & Utrecht & NL31 & 8 \\
\hline Prov. Liège & BE33 & 2 & Noord-Holland & NL32 & 8 \\
\hline Prov. Luxembourg (BE) & BE34 & 2 & Zuid-Holland & NL33 & 8 \\
\hline Prov. Namur & BE35 & 2 & Noord-Brabant & NL41 & 8 \\
\hline Brandenburg & DE41 & 2 & Limburg (NL) & NL42 & 8 \\
\hline Mecklenburg-Vorpommern & DE80 & 2 & Bratislavský kraj & SK01 & 8 \\
\hline Thüringen & DEG0 & 2 & Illes Balears & ES53 & 9 \\
\hline País Vasco & ES21 & 2 & Lombardia & ITC4 & 9 \\
\hline Comunidad Foral de Navarra & ES22 & 2 & Veneto & ITD3 & 9 \\
\hline Aragón & ES24 & 2 & Emilia-Romagna & ITD5 & 9 \\
\hline Comunidad de Madrid & ES30 & 2 & Toscana & ITE1 & 9 \\
\hline Border, Midland and Western & IE01 & 2 & Praha & CZ01 & 10 \\
\hline Southern and Eastern & IE02 & 2 & Berlin & DE30 & 10 \\
\hline Piemonte & ITC1 & 2 & Bremen & DE50 & 10 \\
\hline Liguria & ITC3 & 2 & Hamburg & DE60 & 10 \\
\hline Friuli-Venezia Giulia & ITD4 & 2 & Castilla y León & ES41 & 11 \\
\hline Umbria & ITE2 & 2 & Castilla-la Mancha & ES42 & 11 \\
\hline Marche & ITE3 & 2 & Extremadura & ES43 & 11 \\
\hline Lazio & ITE4 & 2 & Cataluña & ES51 & 12 \\
\hline Abruzzo & ITF1 & 2 & Andalucía & ES61 & 12 \\
\hline Friesland (NL) & NL12 & 2 & Övre Norrland & SE33 & 13 \\
\hline Drenthe & NL13 & 2 & Sachsen-Anhalt & DEE0 & 14 \\
\hline Flevoland & NL23 & 2 & & & \\
\hline Zeeland & NL34 & 2 & & & \\
\hline Galicia & ES11 & 3 & & & \\
\hline Principado de Asturias & ES12 & 3 & & & \\
\hline Cantabria & ES13 & 3 & & & \\
\hline La Rioja & ES23 & 3 & & & \\
\hline Región de Murcia & ES62 & 3 & & & \\
\hline Molise & ITF2 & 3 & & & \\
\hline Basilicata & ITF5 & 3 & & & \\
\hline Západné Slovensko & SK02 & 3 & & & \\
\hline Stredné Slovensko & SK03 & 3 & & & \\
\hline Východné Slovensko & SK04 & 3 & & & \\
\hline
\end{tabular}

Source: Authors' work 